\title{
6 GENDER, DEVELOPMENT AND PEACE
}

\section{Peter Ninnes}

The previous chapters have described Leitana Nehan's work over the last 12 years. We have attempted to show how the work conducted by the organisation has changed over time in response to the changing situation on the ground in Bougainville. We have also described the way the organisation has been able to build up the abilities and capacities of its staff and volunteers, and partner with a range of local, national and international organisations. In this and the following chapters we adopt a more analytical approach and attempt to explain in more detail the reasons why Leitana Nehan has been able to continue to grow and expand its work to a variety of social sites and institutions. There are many reasons for the Leitana Nehan's successful expansion and growing influence, including the social standing of its founders and their spouses, and of the volunteers, the commitment and hard work of its founders and subsequent staff and volunteers, the willingness of partners to contribute to the work, and the ability of the organisation to change and adapt to new circumstances. However, another major reason is the organisation's ability to take up, use, promote and gain acceptance for its vision for Bougainville, and particularly for its ideas about the role of women in Bougainville society, its vision of peace, and its ideas about development. In this chapter, therefore, I analyse how over time the organisation and its workers have conceptualised gender, development and peace, and how these conceptualisations have changed in response to changing contexts on Bougainville.

In essence I am exploring how Leitana Nehan's power operates. This is not a power that is oppressive or hierarchical; rather, as Foucault 
(1991:194) observed, power is productive- it produces reality; it produces domains of objects and rituals of truth'. In other words, it is through the operation of power that we come to understand and interpret the world and our place in it. Leitana Nehan's work in conveying particular ideas about women, peace and development therefore can be seen as a struggle to change the way people view the world, and in particular Bougainville, and their place in it. Most of this work of changing the way people view the world occurs through the use of language in particular contexts. Actions also have a major part to play by setting examples of how to behave. Nevertheless, the meanings of these actions are not transparent, but are explored and understood by and through language. In this chapter, therefore, i focus on language and in particular the discourses about women, development and peace that Leitana Nehan has used over time. Discourses are often the means through which power operates. Thus, they too are productive, since they 'systematically form the objects of which they speak' (Foucault 1972:49).

In the case of Leitana Nehan, these discourses have been deployed in two particular contexts, apart from the obvious ones of the crisis and its aftermath. The original founders of Leitana Nehan were already active in leadership roles in the Bougainville Diocese of the Catholic Women's Association prior to the conflict. Since the majority of Bougainville people are affiliated with the Catholic Church, these leadership roles and the CWA network provided a ready-made template on which to graft peacebuilding work. Second, and probably more fundamentally, Agnes, Helen, Brenda and Alina all hold chiefly positions in the social structure of their clans in Nissan and central, south and north Buka respectively. Thus they have respected and influential social connections throughout Nissan and Buka. Furthermore, within Bougainville societies, there are also chiefly connections across clans, and in some cases this meant that the Leitana Nehan founders had connections on the mainland of Bougainville as well. As I showed in Chapter 4, these connections were sometimes used to expand Leitana Nehan's work into various districts in Bougainville.

In the following analysis, I show how Leitana Nehan, through its founders and associates, has productively used, in the contexts described above, three sets of discourses around gender, development 
and peace. These deployments have for the most part been productive in the sense that they have allowed the organisation to recruit a growing cohort of volunteers; obtain approval to conduct their programs in a rising number of villages, schools and other social institutions; promote their work to, and create philosophical and financial partnerships with, a range of local, national and international organisations; and ensure women's issues are considered at various levels of the peace-building process, including disarmament talks and constitutional committee meetings. I analyse a range of official Leitana Nehan documents, as well as data from the interviews with Leitana Nehan founders, paid employees and volunteers.

\section{WOMEN AND GENDER}

Leitana Nehan has employed a range of the wide variety of discourses of gender that circulate globally and that have been identified by Tong (1998). In its first few years, Leitana Nehan tended to deploy culturally oriented discourses of gender that emphasised the important roles that Bougainville women have traditionally played in Bougainville societies. As Helen noted, the early emphasis was on improving family life. Mothers give birth to men and children. Since mothers are custodians of the land they are therefore leaders in improving family and community life. The purpose of using these discourses was to attempt to re-establish women's social roles, which had been eroded by colonialism prior to 1975 , the mining operations and their associated social disruption (see also Wesley-Smith and Ogan 1992), and by the ten years of civil war.

In the mid 1990s, and particularly after two key members of the organisation, Helen Hakena and Agnes Titus, attended the International Women's Forum in Beijing in 1995, Leitana Nehan began to deploy liberal discourses of enhancing women's opportunities and protecting and promoting women's rights. This was partly a result of discussions that Helen and Agnes held with women in parishes on Buka, who decided 'women's rights' were compatible with what they needed. The women realised they needed to speak out (as was their right) because the men were bagarap (incapable) and too scared to speak. 
These liberal discourses of women's rights are reflected in Leitana Nehan documents. For example, article 3.6.1 of the Leitana Nehan constitution (LNWDA 1997) states that one of the organisation's aims is

[t]o promote, maintain and protect the interests, rights and privileges of the women of Bougainville irrespective of religion, colour, creed or affiliation.

The proposal submitted by Leitana Nehan and IWDA to AusAID for the Strengthening Communities for Peace project indicated that one of the proposed outputs would be increased awareness throughout Bougainville Province, Papua New Guinea and the Pacific about women's rights and concerns' (LNWDA and IWDA 1999:3). Similarly, the 2000 Annual Report notes that the overall goal of the SCP project is to 'contribute to the restoration of peace in Bougainville by promoting non-violence and women's rights' (LNWDA 2001a:10).

A promotional brochure produced in 2001 takes up the theme of women's rights, as well as indicating a concern with enhancing women's social standing.

To meaningfully contribute to restoration of peace in Bougainville by promoting non-violence society and advocacy of women's rights. And also empowering women as agents of change and the improvement of their social status (LNWDA 2001b:n.p.)

Most recently, the Leitana Nehan strategic plan (LNWDA 2003a) identified the promotion of rights as one of its key strategic priorities, and in this case the discourse of women's rights has been extended to include children's rights. For example, the strategic plan (LNWDA 2003a) states that the organisation exists for 'the promotion of women and children's rights'. According to one of the monthly reports for the SCP project (LNWDA 2003b), one of the achievements of the project has been the inclusion of a statement on women's and children's rights in the draft constitution for an autonomous Bougainville.

Leitana Nehan also deployed a discourse focused on international conventions and national obligations to strengthen its claims concerning women's and children's rights. This is a practice that ChanTiberghien (2004) refers to as leverage politics. It involves using the ideas, status and standing of international conventions and declarations to lobby for change at the local level. The 1999 Annual Report, for example, stated 
Leitana Nehan in a small way carries out public awareness on the rights of women stipulated under the Papua New Guinea constitution and any other international laws and declarations issues under the United Nations charter (LNWDA 2000a:6).

Furthermore, the 2004-07 Strategic Plan (LNWDA 2003a:5) states that the organisation promotes these rights 'as stipulated in the Convention on all Forms of Violence against Women (CEDAW) and the Convention on the Rights of the Child (CRC)'.

Another impact of the Beijing forum was that Leitana Nehan openly eschewed certain elements of separatist radical feminist discourses (Tong 1998) that excluded men from contributing to the organisation's work. Rather, they argued that in Bougainville societies women, men and children work together, and therefore it would be inappropriate to adopt a separatist stance. ${ }^{2}$ Furthermore, as one founder noted in the margin of the interview transcript which she proofread

[i]f we confine gender issues to women only to deal with, then it will be seen as women's issues. But we are involving men to make them feel they are part of the issue and it is their issue, too. So the problems are community issues to be worked out together, by men and women.

Thus, in a submission to International Alert (LNWDA 2000b), Leitana Nehan stated: 'The issue on gender development has to be aggressively promoted to enable men and women [to] work hand in hand on issues and programmes affecting their lives'. Similarly, in the 2000 Annual Report (LNWDA 2001a:10), Leitana Nehan stated

[t] here is a big need for men to see women as equal partners in all areas of development. Bougainville men and women need to work together hand in hand to find a lasting peaceful solution to the armed conflict on Bougainville.

Leitana Nehan also uses other cultural discourses of gender, particularly when lobbying for women's representation at disarmament talks and other public political forums that men attempt to dominate numerically. These cultural discourses argue that Bougainville women have a unique place in Bougainville societies and therefore particular roles to play in peace-making and post-conflict recovery. This is a form of what Tong (1998:47) calls a radical cultural feminism in which ' $[w]$ omen should not try to be like men...they should try to be more like women, emphasising the values and virtues culturally associated with women'. For example, in the SCP proposal 
(LNWDA and IWDA 1999:5), the coordinator of Leitana Nehan was quoted as saying, 'Our women feel that their potential and capabilities in helping with rehabilitation and development need to be recognised because they hold important keys no one else can turn'. Similarly, in the 2000 Annual Report (LNWDA 2001a:10), Leitana Nehan argued, 'Women have a special place in the Bougainville society....as a result of the matrilineal system that existed on Bougainville'. The Leitana Nehan promotional brochure, also takes up this theme.

We recognise and endeavour to build upon capacities of people to resolve their own conflicts and we support the distinctive peace making roles of women in societies affected by the violent conflict (LNWDA 2001b:n.p.).

In some contexts, such as international forums, Leitana Nehan deploys global feminist discourses, in which all women are viewed as part of a sisterhood, despite their differing experiences of oppression (Tong 1998:242). For example, in a speech in Melbourne marking International Women's Day in 2003, Helen Hakena (2003a) addressed her audience as 'sisters'.

\section{DEVELOPMENT}

In terms of development, there has been a shift in the emphasis that the organisation places on social, cultural and economic change. In its original form as a humanitarian relief organisation, Leitana Nehan provided clothes and medicine for women and children who had been moved from the war zones into 'care centres' by the PNG military (see Chapter 2). Later, the organisation began to emphasise development. For example the Leitana Nehan Constitution (LNWDA 1997:n.p.) states that one of the organisation's objectives is 'to work towards the improvement of the living standards of the women of Bougainville so as to enable them to achieve gradual economic and social development'. By the end of the 1990s, however, and with a truce in the war, Leitana Nehan began to emphasise integral human development (IHD), based on certain Catholic teachings that argue that economic and infrastructure development is premature without personal, spiritual and moral development. For example, in the SCP proposal, one of the major activity outputs was to be 'a mutually supportive network formed 
of 120 community representatives able to work with their communities in an ongoing fashion using IHD principles to address social problems' (LNWDA and IWDA 1999:3). The same document gave a detailed description and rationale for IHD.

IHD provides a holistic approach to community development that highlights the inter-relatedness of social problems. The IHD workshops will explore the wide range of factors that cause violence and disharmony in the community, including, anger, grief, fear, trauma and lack of self understanding, lack of self worth and insufficient guidance/direction for young people...the workshops will aim to equip the community representatives with the tools to facilitate psychological, emotional and spiritual rehabilitation, and to motivate communities to creatively address social problems (LNWDA and IWDA 1999:10).

This illustrates the priority given to non-material development as a prerequisite for economic and physical development. Other documents provide further insight into the reasons for this priority. For example, the 1999 Annual Report (LNWDA 2000a:1) states that IHD is a priority because 'many Bougainvilleans were traumatised and suffered a lot during the ninth [sic] year armed conflict on Bougainville'. Furthermore, the 2000 Annual Report (LNWDA 2001a:1) states, 'the focus on Integral Human Development must be given priority in order for Unity, Peace and Development to prosper on Bougainville'. Leitana Nehan tends to view IHD as 'people-centred development'. In its promotional brochure (LNWDA 2001b:n.p.), it states, 'above everything else, men, women and children of Bougainville shall be at the centre of any form of development politically, economically, socially, spiritually and culturally'. Most recently, the organisation's strategic plan has continued to emphasise holistic development.

The organisation will practise a holistic approach to development that encompasses physical, spiritual, social and economic well being. Leitana Nehan believes that each person deserves an opportunity to develop, to the fullest possible extent, his or her own physical, mental, emotional and spiritual potential (LNWDA 2003a:5).

For several years, Leitana Nehan has promoted integral human development as a prerequisite to economic and infrastructure development. We believe that any form of development should improve the quality of life for all Bougainvilleans (LNWDA 2003a:3). 
It is noteworthy that in both of the above passages, there is a shift from the 1997 constitution, which focused solely on women's development. In the 2004-07 Strategic Plan, the vision has expanded to improving the quality of life for all Bougainvilleans.

Many of the interviewees subscribed to the integral human development model. When asked what development was, they mentioned ideas such as assisting people to know and understand themselves and relate to others; developing respect for other people; that development had mental, physical, spiritual and social dimensions; that it involved the whole person; creating good people; changing attitudes and behaviours, including one's own; decreasing the number of troublemakers; and ridding the community of bad things such as homebrew, domestic violence and child abuse. One interviewee suggested that development was about training and informing the public about issues, providing opportunities to debate issues, and knowing the differences between various approaches to dealing with specific issues. Some interviewees, when defining integral human development, contrasted it with models that focused only on infrastructure, such as buildings, schools, bridges and rainwater tanks. One interviewee, however, argued that development did involve 'schools, trade stores and providing services to the people'. One interviewee argued it was no use building schools and clinics if people were in the frame of mind to burn them down, which is what happened during the war, and therefore it was important to deal with the psychological trauma of the war before re-establishing infrastructure. According to another interviewee, reconciliation as well as psychological healing is necessary so that people trust each other and can work together to improve their lives. This interviewee cited two instances in which an outside aid organisation had implemented programs before adequate levels of reconciliation and healing had occurred. In one case, the program had sapped people's initiative and led to a hand-out mentality, while in the other case it had made people suspicious of the aid organisation's local partner, with the result that the local partner had to work hard to allay these fears. 
Some of the interviewees who advocated IHD also argued that development involved employment generation projects, such as those that supplied sewing machines, ovens or seeds, or provided for the creation of other small businesses. There was a sense that people needed to be gainfully employed so that they did not go back to making homebrew and causing trouble. One interviewee also observed that such projects worked best when focused on the extended family, rather than the whole community.

The source of a substantial proportion of Leitana Nehan's ideas on IHD is a book by a Catholic Priest, Father Tony Byrne (1983), which focuses on 'integral development', although in the Leitana Nehan documents the work 'human' is inserted in the phrase. Byrne (1983:6) cites Pope Paul VI's 1967 book, The Development of Peoples, which defines development as the 'promotion of the good of people, every person and the whole person', rather than the development of material things such as buildings. The book promotes a consultative, participatory model of development, and advises against paternalistic approaches. At the same time, it treats the question of gender equality dismissively, as evidenced by the following anecdote.

Some time ago I asked a group of people attending a development seminar to draw their idea of development. One Sister who was attending the seminar had a good sense of humour. She drew a picture of a Sister wearing a bishop's mitre ... I suppose we will have to wait for some time before we have that kind of development! (Byrne 1983:6).

Yet the 2004-07 Strategic Plan makes it quite clear that Leitana Nehan itself highly values gender equality.

The promotion of gender equality is an underlying principle of the organisation... The organisation will promote and practise equal participation by women and men in all aspects of Leitana Nehan operations. It is important that the organisation serve as a role model of gender equity (LNWDA 2003:5).

This is an example of the way in which Leitana Nehan selectively appropriates discourses of development and gender that they consider useful to them at particular points in time. Further examples are found in recent documents, which consecutively take up three other development discourses. First, starting in the late 1990s, Leitana Nehan used a discourse of empowerment. Initially, the focus was on the 
empowerment of women. The SCP proposal (LNWDA and IWDA 1999:3) aims to have 'women around Buka and Bougainville Islands empowered by access to counselling, basic legal advice and referrals to lawyers to extricate themselves from abusive domestic situations'. Similarly, the 2001 promotional brochure states (LNWDA 2001b) that Leitana Nehan has the aim of 'empowering women as agents of change and the improvement of their social status'. Yet Leitana Nehan also argues for broader levels of empowerment. The 2000 Annual Report argues, 'youth empowerment is the key to Youth Development on Bougainville' (LNWDA 2001a:11). The 2004-07 Strategic Plan (LNWDA 2003a:5) also recommends empowerment for the population in general, since 'empowering communities and their organisations' is one of the five strategic areas in the plan, and 'Leitana Nehan recognises that people have the right to organise in pursuit of their own interests and should be empowered to define and lead their own development efforts'.

Several of the interviewees mentioned these kinds of ideas when discussing development. One of the Leitana Nehan founders said development involved 'empowering women to be agents of change', while one volunteer said development meant 'developing women to exercise their rights', as well as helping men to understand women's rights and not think of them as servants or slaves. One of Leitana Nehan's project officers said that development involves making women aware of their rights and of where to get help when they need it, and to involve women in decision-making.

Second, the discourse on capacity-building appears around about the year 2000. The 2000 Annual Report describes workshops that had been run that year to 'build capacity' of Buka youth (LNWDA 2001a:9) and Siwai women (LNWDA 2001a:11), while similar workshops were run in 2001 for Buka women (LNWDA 2002a:5). The current strategicplan also deploys this discourse, particularly with respect to the organisation itself, which lists ' $[s]$ trengthening the capacity and sustainability of LNWDA' as one of its five strategic areas (LNWDA 2003a:1). None of the interviewees specifically mentioned capacity-building, although one team leader did mention that development involved increasing people's skills in areas such as business management. 
A third and more recent development discourse focuses on 'good governance'. This discourse first appears in the title and content of the 2004-07 Strategic Plan (LNWDA 2003a). One of the strategic areas in the plan is 'practising good governance', while a goal of the plan is ' $[\mathrm{t}] \mathrm{o}$ promote good governance within the organisation and in our relationships with key stakeholders' (LNWDA 2003a:15). Among other things this is to be done by having 'appropriate policies and procedures... in place to ensure accountability and transparency' (LNWDA 2003a:15). Although good governance appears as a discourse in official documents, none of the interviewees mentioned it specifically as a component of development.

Some interviewees identified a cultural component to development, which had two dimensions. First, some interviewees saw development as involving a return to the lifestyle or customs that existed before the war. For two interviewees, development meant moving towards attaining sindaun bilong bifo (life in the past), in which traditional customs were followed such as sharing, speaking properly, respect, working together and not fighting. For one of these interviewees, development also meant reducing the impact of custom on women's rights. Second, one interviewee noted that development projects have to be compatible with, and fit in with, ceremonial schedules. For example, participants in a development project should observe the ten-day mourning period after a funeral and obtain permission from the chiefs before recommencing work.

\section{PEACE}

Like the discourses of gender and development, the discourses of peace employed by Leitana Nehan have shifted in response to the changing situation in Bouganville. The Leitana Nehan constitution (LNWDA 1997), which was developed at about the same time that the 1997 truce came into effect, lists as objectives of the organisation 'women's integration into the reconciliation, reconstruction and rehabilitation process of Bougainville' (article 3.4) and 'to assist and partake in the peace process of Bougainville thus ensuring that normalcy returns to Bougainville' (article 3.10). The former article in particular indicates an emphasis on participating in three of the 
major tasks of post-conflict recovery. The triumvirate of reconciliation, reconstruction and rehabilitation has persisted into the discourse in the current strategic plan, with an acknowledgement of the interlinked contributions of a range of actors at various social levels.

Bougainville is now on the road to recovery. We are in the process of rebuilding our lives and restoring essential services. Reconstruction, reconciliation and rehabilitation are people's highest priority. Peace-building programs are being implemented in all areas on Bougainville, supported by communities and assisted by churches, NGOs, the government and international aid agencies (LNWDA 2003a:4).

The SCP proposal (LNWDA and IWDA 1999) shifts the 'peace' emphasis from the crisis, which effectively finished in terms of armed conflict in 1998, to violence in general and against women in particular when it argues that the overall goal of the project is to 'contribute to the restoration of peace in Bougainville by promoting non-violence and women's rights' (LNWDA and IWDA 1999:6). Identical wording is used in the SCP Year 2 annual plan (LNWDA and IWDA 2001:4). Reconciliation was a particular aim of the youth mobilisations described in Chapter 3. The 2000 Annual Report reflects this when it states that one of the aims of the Tinputz youth mobilisation was to 'bring together youth as a means of promoting peace, unity and reconciliation among youth' (LNWDA 2001a:9). In addition to reconciliation, the organisation has emphasised emotional and psychological healing as an important component of the peace-building process.

Weapons can be containerised and disposed of, expensive infrastructure can be built, with assurance of a better and brighter future by leaders. However, peace will be just a dream if people's minds are not healed (Hakena 2003a:n.p.).

The discourses of gender and peace intersect. In particular, the radical culturalist feminist discourse that identifies unique social and cultural roles for women, described above, is employed to explain the role of women in both peace-making and post-conflict recovery.

It was the women who risked going out into the jungle to persuade our sons, husbands and brothers to avert war. It was the women who really made peace, not 
the menfolk. They were busy killing, destroying and raping women (Hakena 2003a:n.p.).

Women are not passive victims. We are contributing actively to peace-making. Our courage and contributions have made the world a better place to live and work. Imagine what more we could do if we women were enabled to take a more equal place at the negotiating table (Hakena 2003a:n.p.).

The volunteers and staff members interviewed for this study defined peace in terms of particular absences and presences. The most common definition, mentioned by nine respondents, was that peace means to have a good life, to stap gut or have a gutpela sindaun. Six respondents said that peace meant 'freedom', which is not surprising because during the war freedom of movement was curtailed, with many displaced persons in the government-controlled areas confined to care centres and those behind the BRA lines unable to cross the blockade (see Sirivi and Havini 2004). Three or less respondents mentioned other components of peace, including contentment, satisfaction, respect for others, respect for property, abiding by the law, peace (bel isi), reconciliation, cooperation between people, loving each other, living as one, listening to chiefs, being happy (amamas), enjoying life, respect for traditional values, having basic needs met, being settled, and brukim bonara, wokem bikfala kaikai, wokem lotu (that is, the traditional peace-making rituals of breaking weapons, having a feast and a church service-see Howley 2002; Fisher 2004).

In terms of absences, there were a wide variety of responses. The most common were that peace involved an absence of violence (four respondents), war (three respondents), fighting (two respondents), threats (two respondents), fear (two respondents), and harassment (two respondents). Individual respondents also mentioned an absence of danger, disturbances, discrimination against women, retaliation, trouble, the desire to kill, problems (hevi), stealing, use of weapons, land disputes, hatred and alcohol-related crime.

In general, the respondents showed an understanding of peace that went beyond simplistic definitions of peace as the absence of war. In particular, there was an emphasis on the quality of life, both for individuals and for groups. A similar level of sophistication was displayed concerning respondents' understanding of the causes of 
peace. A common response was that peace begins with a change in one's own perspective. One respondent said that 'a change in people is needed; a transformation to respect others as oneself'. Another said that 'peace grows from within us...realising what I've done wrong to the other person'. A third person said that peace was the result of lustingting olsem pait, stil (forget about doing things like fighting and stealing). A fourth said that peace was the result of a spiritual change, while a fifth said that peace involved 'rehabilitation of the minds of the people'. The heart was considered by a number of respondents to be a locus for initiating peace: 'it has to come from the bottom of your heart', and 'genuine peace comes through the heart' were two responses. Alternatively, families were considered by some respondents to be a starting point for peace-making. One respondent said peace 'must start with the family', while another said that 'children must respect parents na tok tok gud long famle [and speak respectfully to family members] in order to make a different community'.

A number of respondents argued that, once individuals were at peace with themselves, this would have a flow-on effect. One respondent said Emi stat long ol wan wan man na emi save go long famle na long ples (it [peace] starts with individuals, then spreads to the family and community). Another said, 'we have to produce peace in ourselves, then the family, community, district and province'.

For some respondents, the spreading of peace described above was not inevitable, but required actions such as cooperation, a collective effort, hard work, reconciliation, forgiveness and trust-building. One respondent suggested that it is necessary to reconcile, admit failures, give compensation and return stolen property. Another respondent indicated faith in traditional methods: 'not just shaking hands, but killing a pig and giving it, witnessed by the chiefs'. On the other hand, two respondents were sceptical of the efficacy of traditional reconciliation methods. One said peace is "just a handshake and a feast. That's superficial and won't last... [we] need to address all the unfinished issues such as polygamy, stealing, adultery, domestic violence'. Another said, 'reconciliation feasts won't work if it doesn't come from the heart'. 
While most of the respondents saw peace as a process that involved individuals, family and community transformation, only one respondent took a more external, political view that reflected some of the issues that provoked the Bougainville crisis. He argued that sipos jastis emi kamap bai pis emi kamap (if there is justice, then there will be peace)', and that if independence comes, then peace will come.

A number of respondents discussed the consequences of peace when defining peace and its causes. Apart from general comments about making communities better places to live, six respondents mentioned that peace meant that health and education services could be available, and other development work could be done. During the blockade, these kinds of services were difficult or impossible to maintain (see Sirivi and Havini 2004), and one of the major arguments used to promote the peace process and to encourage reluctant ex-combatants to join has been the promise of the so-called peace dividend, namely improvement of living conditions and restoration of services (see, for example, Barter 2004). One of the founders' spouses developed this point by remarking that peace-building was not just about reconstructing the economy, but also about reconstructing morals and culture.

\section{NOTES}

${ }^{1}$ Interview, Helen Hakena, 19 February 2004.

${ }^{2}$ Interview, Helen Hakena, 19 February 2004. 